\title{
THE PERILS OF “CONSENSUS”: HANS KELSEN AND THE LEGAL PHILOSOPHY OF THE UNITED NATIONS
}

\section{J. Peter Pham*}

During the debates preceding Operation Iraqi Freedom, ${ }^{1}$ most Americans, even those who usually consider themselves seasoned political observers, were surprised at the vehemence with which many at the United Nations and other international assizes not only opposed the specific policies of President George W. Bush and his administration, but also contested the very notion that the United States government could be permitted to stake a unilateral position that is different from the consensus of the world body. Even prescinding from the specific case of the military intervention in Iraq by the armed forces of the United States and its allies, many at the United Nations and the various nongovernmental organizations (NGOs) that, together with the U.N. and its bureaucracy, pass nowadays as the institutional incarnation of the international community, have excoriated the United States in recent years for its unilateralism, refusing to defer to the multilateral international consensus on such matters as the Kyoto Protocol on environmental change, ${ }^{2}$ the Ottawa Treaty banning anti-personnel land mines, ${ }^{3}$ and the Rome Statute creating the International Criminal Court. ${ }^{4}$

There are a number of different explanations proposed for these tensions. According to one school of thought, tensions and even heated exchanges have been and are part and parcel of international diplomacy. Hence, the exponents of this explanation counsel to do nothing: allow time to pass and tempers to cool, recognize that, as former U.S. Ambassador to Saudi Arabia, Charles W. Freeman, Jr. observed, estrangement from former friends invites charges of perfidy, but a state's bargaining power is usually enhanced, rather than

* A former international diplomat and frequent commentator on foreign affairs, J. Peter Pham is the author, most recently, of LIBERIA: PORTRAIT OF A FAILED STATE (2004). He holds a doctorate in ethics as well as European graduate degrees in international, administrative, and canon law. Thanks to Professor Ronald D. Rotunda (George Mason University School of Law) for his helpful comments.

1. See U.S. Army: Operation Iraqi Freedom Homepage, at http://www.army.mil/operations/oif (last visited Mar. 23, 2004).

2. Kyoto Protocol to the United Nations Framework Convention on Climate Change, adopted Dec. 11, 1997, 37 I.L.M. 32, available at http://unfccc.int/resource/convkp.html (last visited Mar. 31, 2004).

3. Convention on the Prohibition of the Use, Stockpiling, Production and Transfer of Anti-Personnel Mines and on their Destruction, adopted Sept. 18, 1997, 36 I.L.M. 1509, available at http://www.unog.ch/frames/disarm/distreat/ottawa.htm. (last visited Apr. 1, 2004).

4. United Nations Diplomatic Conference of Plenipotentiaries on the Establishment of an International Criminal Court, Rome Statute of the International Criminal Court, 17 July 1998, U.N. Doc. A/CONF/189/9, reprinted in 37 I.L.M. 999, available at http://www.un.orgllaw/icc/ (last visited Mar. 31, 2004). 
impaired, by demonstrating its freedom of diplomatic maneuver in pursuit of national interests. ${ }^{5}$

A variant of this approach is the temptation to write off this criticism, especially in light of the French government's volte-face from promising to veto any U.N. Security Council resolution authorizing the use of force in Iraq to demanding French firms share in the lucrative post-war reconstruction contracts being awarded by the Coalition Provisional Authority (CPA), ${ }^{6}$ as a momentary tempest in a teapot, fueled by the puerile feelings of impotence in the face of the world's lone hyperpuissance (to recall former French foreign minister Hubert Védrine's less-than-affectionate designation for an America he viewed as too worryingly-powerful to be designated a mere "superpower").

Other observers have sought to attribute these tensions to what they perceive as a lack of leadership and effectiveness in American participation at the United Nations and other multilateral organizations. Such was the conclusion of a blue-ribbon, bi-partisan task force co-sponsored by the Council on Foreign Relations and Freedom House and co-chaired by Congressman David Dreier and former Congressman Lee H. Hamilton. ${ }^{8}$ Congressman Dreier and Congressman Tom Lantos introduced to the House of Representative the recommendations of the task force for tactical and institutional reforms of the U.S. missions to the United Nations and other international organizations. ${ }^{9}$

Such approaches to the current tensions, while completely justified in se, suffer nonetheless from their failure to take into account the long-term significance not only to the policy interests of the United States, but for the international system itself of raising consensus to the status of a norm in international organizations like the United Nations. What is at stake is not

5. Charles W. Freeman, JR., ARTS of Power: Statecraft and Diplomacy 82 (1997).

6. For information and news regarding the CPA, see Coalition Provisional Authority, at http://www.cpa-iraq.org (last visited Mar. 24, 2004).

7. For an incisive and convincing analysis of the instinctive opposition to the United States on the part of the European, especially French, governing elites, see JEAN-FRANÇOIS REVEL, L'OBSESSION ANTI-AMÉRICAINE: SON FONCTIONNEMENT, SES CAUSES, SES INCONSÉQUENCES (2002). Ravel, a member of the Académie française, is unsparing in his criticism of his peers, arguing that:

It is lies coming from an anti-American bias that have invented American unilateralism. Tendentious blindness and systematic hostility on the part of many of the governments towards America have weakened them and keep them from an understanding of realities. It is these governments themselves that ... by substituting action with animosity and analysis with passion, have condemned themselves to impotence and, as a result, nourished the American superpower. Id. at 300 .

8. Enhancing U.S. Leadership at the United Nations: Report of an Independent Task Force (2002), available at http://www.cfr.org/publication.php?id=5047 (last visited Mar. 31, 2004).

9. United States International Leadership Act of 2003, H.R. 1590, 108th Cong. (2003). 
simply a question of tactics and more effective public diplomacy. What is ultimately behind the current tensions is a debate concerning legal philosophy, specifically about an ideology that underlies the entire juridical vision of the United Nations, to the detriment not only of the national interests of the United States of America, but also the sovereignty of the nation-state and the democratic self-determination of smaller communities in an increasingly global world. The purpose of the present study is the examination of this philosophical vision, its intellectual origins, its current application, and the consequences thereof.

Two terms are essential to understanding the actual terms of the present debate: consent and consensus. Both words derive from the Latin verb consentire (literally cum plus sentire), "to feel together," and, thus, "to agree, to give permission." The notion behind the Latin verb was itself explored in even earlier antiquity, within the context of the Hellenic philosophical inquiry into the nature of freedom. To the Stoics, who knew the concept in Greek as synkatathesis, it denoted a spiritual assent or accord to a proposition. The modern use of the verb "to consent" (consentir in its Old French origins) dates at least back to the writings of Richard of St. Victor (ca. 1110-1173). ${ }^{10}$ In English, the use of the noun "consent" signifies "agreement" or "permission" and dates back to at least 1225." In its millennial usage, as both verb and noun, the word has implied an individual act wherein a truth proposed is affirmed. Thus, the authors of the American Declaration of Independence held that "governments are instituted among men, deriving their just powers from the consent of the governed," that is, from the willful and explicit act of agreement of the governed to being ruled, an active act. ${ }^{12}$

In contrast, apart from its technical use in the Latin of the medieval Church's canon law, the now much-used noun "consensus" was relatively rare. Its use in modern languages is relatively recent, being a product of the philosophical enlightenment and entering the English language only in the 19th century, specifically in 1843 , according to the second edition of the Oxford English Dictionary. And while the word "consensus" derives from the same linguistic roots as its cousin "consent," consensus took on a slightly, but significantly, different meaning. Rather than an affirmation of truth, consensus occurs when, in the words of French philosopher Paul Foulquié,

10. See GeRvaIS DuMEIGE, RICHARD DE SAINT-VICTOR ET L'IDEE CHREtIENNE DE L'AMOUR (1952) (illustrating Richard of St. Victor's use of “consent."). While Richard, the Scottish-born abbot of the Parisian Cistercian Abbey of Saint Victor, is best known for his writings on Christian spirituality, it was within the context of his development of a theology of the Trinity that he articulated an early psychology of consent. Id. See also RICHARD DE SAINT. VICTOR, DE TRINITATE: TEXTE CRITIQUE AVEC INTRODUCTION, NOTES ET TABLES (JEAN RIBAllLIER ed.) (Librairie Philosophique J. Vrin, 1958). No less a figure than Dante characterized Richard's thought on the matter as "in contemplation more than human" ("che a considerar fu più che viro," Paradiso X, 130).

11. See DUMEIGE, supra note 10.

12. Id. 
"one gives to the decision that another initiated the personal adhesion necessary for it to pass into fulfillment." ${ }^{13}$ That is, it is a passive acquiescence to an act that has no necessary correlation to objective truth.

This philosophical subtlety is crucial to understanding the indignation sparked by America's repudiation of what is presented as the "consensus" of the world. With enlightenment thinkers, such as Immanuel Kant, excluding considerations of the metaphysical from the public square, there emerged a paradox. Democracy is based on the equality of all, and freedom of thought, speech, and association, which gives rise to the "consent of the governed." However, when other principles are excluded, the democratic process becomes an absolute and majority rule risks causing a democratic society's values to be determined by a preponderance of voices that, for the sake of appearing legitimate, masquerade as an impersonal general will, or "consensus." Having no point of reference other than a vote count of nation-states and, increasingly, self-appointed NGOs, the United Nations, and other international groups increasingly rely on "consensus" to legitimize their deliberations. A classic illustration of this is the opprobrium heaped upon the United States for being in the "extreme minority" and defying "consensus" in rejecting the Ottawa and Rome accords, when the majorities adopting both agreements consisted of states representing less than half of the world's population. ${ }^{14}$ Thus, the hypothetical "tyranny of the majority" that Alexis de Toqueville cautioned against ${ }^{15}$ has become real in the contemporary international community's de facto "tyranny of consensus" and, often enough, it is the "consensus" of a vocal minority at that.

All of this comes by way of preface to the present situation in which the United States finds itself regularly confronted by an "international community," as represented by the United Nations and those NGOs whose globalist agenda matches the ambitions of the U.N. bureaucracy to world governance, demanding that it give up its "unilateral" policies and submit to an alleged "multilateral consensus." This attitude, rather than being merely a reaction to the unique set of historical circumstances that left the United States, in the words of former President George H. W. Bush, the world's "sole and preeminent power"17 with all the attendant resentment such a status inevitably

13. PaUl FoulquiÉ, DictionNAIRE DE LA LANGUE PHILOSOPHIQUe 126-27 (1st ed. 1962) (defining "consentment").

14. See generally David Davenport, The New Diplomacy, POL'Y REV., Dec. 2002, at 17 30, available at http://www.policyreview.org/DEC02/davenport.html (last visited Mar. 25, 2004) (reviewing the role of a small group of states allied with globalist NGOs in formulating the international "consensus").

15. See generally ALEXIS DE TOQUEVILLE, DEMOCRACY IN AMERICA (J.P. Mayer ed. \& George Lawrence trans., Anchor 1969).

16. See generally John Van Oudenaren, What is “Multilateral?”, POL'Y REV., Feb. 2003, at 33-47, available at http://www.policyreview.org (last visited Mar. 23, 2004).

17. George H. W. Bush, State of the Union Address (1992), available at http://www.janda.org (last visited Mar. 6, 2004). 
brings and, therefore, destined to dissolve once some future rival rises to balance America's political, economic, and military might represents a longterm ideological commitment inherent to the United Nations bureaucracy and the supranational legal system that is its goal to bring about, as U.N. SecretaryGeneral Kofi A. Annan has candidly admitted:

Simply put, our post-war institutions were built for an international world, but we now live in a global world. Responding effectively to this shift is the core institutional challenge . . . More than ever, a robust international legal order, together with the principles and practices of multilateralism, is needed to define the ground rules for an emerging global civilization. .... ${ }^{18}$

This drive to subsume national sovereignty within single "multilateral consensus" derives its theoretical foundations from the legal philosophy of Hans Kelsen, one of the most important jurists of the twentieth century, if not the most preeminent. ${ }^{19}$ Although Kelsen's theory has long been the focus of legal scholars around the world, and despite the fact that he spent the last three decades of his life teaching in the United States, only recently have American scholars begun to examine his thought, ${ }^{20}$ a state of affairs that goes a long way to explaining the lack of appreciation in U.S. policy circles of the deeplyrooted nature of the hostile attitudes that confront the country's independent international policy.

Kelsen is relatively unknown in American circles. The only complete biography of him to date, by his former student and assistant Rudolf Aladár Métall, was published in German ${ }^{21}$ and remains untranslated. Therefore, it would be useful to recount the major events in the fascinating life of the legal

18. Kofi A. ANNAN, "WE THE PEOPLES": THE ROLE OF THE UNITED NATIONS IN THE 21 ST CENTURY 11, 13 (2000).

19. See Michael Steven Green, Hans Kelsen and the Logic of Legal Systems, 54 ALA. L. REV. 365, 365-414 (2003) (citing a number of legal scholars, qualifying Kelsen as "the most important legal theorist of the twentieth century").

20. See, e.g., RichaRd A. PoSNER, LAw, PRAGMATISM, ANDDEMOCRACY 250-91 (2003). The book has a very recent and interesting exception to this rule, the presence of an entire chapter, entitled "Kelsen versus Hayek: Pragmatism, Economics, and Democracy." Even then, Judge Posner admits that he had never read Kelsen and knew nothing about him except his reputation as a Kantian and the title of his most famous book, Pure Theory of Law, until he was "casting about for a suitable topic for a lecture that [he] had agreed to give at an annual meeting of the European Association of Law and Economics, which was to be held in Vienna" and being "told that economic analysis of law hadn't made much headway in Austria because the academic legal profession there remained under the sway of Austria's (and Continental Europe's) most distinguished twentieth-century legal philosopher, Hans Kelsen." Id. at 250.

21. RudOlf AlADÁR MÉTALl, HANS KELSEN, LEBEN UND WERKE, EINE AUTORISERTE BIOGRAPHIE MIT VOLLSTÄNDIGEN LITERATUR UND SCHRIFTUMVERZEICHNIS (1969). For a complete bibliography of Kelsen's writings listed chronologically and thematically, see ROBERT WALTER, HANS KELSEN: EINE LEBEN IM DIENSTE DER WISSENSCHAFT (1985). 
scholar. ${ }^{22}$ Born in Prague on October 11, 1881, to a German-speaking Jewish family that moved shortly thereafter to Vienna, Kelsen pursued juridical studies even though his lifelong interests were in the humanistic disciplines of philosophy and literature, as some of his legal writings would show. He also had a passion for logic and mathematics as well as the natural sciences. Although a convinced agnostic, he converted to Roman Catholicism in 1905, evidently to escape any problems of discrimination that his religious background might present to his ambitious designs for an academic career in the resolutely Catholic Austro-Hungarian empire.

In 1905, Kelsen published his first book, a study of the theory of the state in Dante. ${ }^{23}$ The following year, he received his doctorate in law from the University of Vienna. In 1911, he qualified as a teacher of public law and of legal philosophy with the publication of his first major work, a 700-page study in which he first articulated his nascent legal theory. ${ }^{24}$ During World War I, Kelsen served as legal advisor to the Austrian Minister of War. In 1918, he was appointed associate professor of law at the University of Vienna, and, after the conflict in 1919, became full professor of public and administrative law. During this period, he was a part of the "Vienna School," coming into contact with Otto Bauer, Max Adler, Joseph Schumpeter, and Ludwig von Mises. Numbered among his students were several figures who would achieve prominence in later years, including Eric Voegelin and Charles Eisenmann. After helping draft the new Austrian Constitution, Kelsen was appointed a member of the Constitutional Court in 1921.

Kelsen's role in leading the Constitutional Court to overturn lower court bans on remarriage, a legal prohibition sought by Catholic Church authorities, caused the Christian Social Party-led government to oust him from the tribunal in 1930. The political climate became so hostile that Kelsen moved to Germany, taking up a chair in international law at the University of Cologne, where he began to focus on positive international law. In 1932, he delivered his second series of lectures in The Hague on this topic. ${ }^{25}$

With the coming to power of the Nazis in early 1933, Kelsen lost his teaching position at the University of Cologne. In the fall of that same year, he immigrated to Geneva with his wife and two daughters to take up a position

22. As yet, there exists no survey of Kelsen's work as a whole in any language. Even the core of Kelsen's work, his "pure theory" of law, has been surveyed in book length only once. See generally WILLIAM EBENSTEIN, THE PURE THEORY OF LAW (1945). Although this book was valid in its time, it became dated with Kelsen's 1960 publication of the second, definitive edition of Reine Rechtslehre [Pure Theory of Law].

23. See generally HANS KeLSEN, DIE STAATSLEHRE DES DANTE ALIGHIERI (1905).

24. See generally HANS KELSEN, HAUPTPROBLEME DER STAATSRECHTLEHRE. ENTWICKELT AUS DER LEHRE VOM RECHTSSATRE (1911). For an English translation, see HANS Kelsen, MaIn Problems in the TheORY OF Public LaW (Stanley L. Paulson \& Bonnie Litschewski trans., 1998).

25. His first, in 1926, had reflected on the relationship between national law and international law. 
at the Institut Universitaire des Hautes Etudes, where he reflected on the integration of international law into national legislation. In 1934, he published the first edition of what would become acclaimed as his masterpiece, Pure Theory of Law. ${ }^{26}$ In addition to his courses in Geneva, he briefly taught international law at the University of Prague, although increasing anti-Semitic agitation made it impossible for him to continue there.

At the beginning of World War II, Kelsen, at the age of sixty, moved to the United States. From 1940 to 1942, he was a research associate at Harvard University, delivering the 1940-1941 Oliver Wendell Holmes Lectures at Harvard Law School that were eventually published as Law and Peace in International Relations. ${ }^{27}$ In 1942, with the assistance of Roscoe Pound who declared him "the leading jurist of the time," professor in the Department of Political Science at the University of California at Berkeley. ${ }^{29}$ In 1945, he became a full professor as well as an American citizen. Remaining at Berkeley until his retirement in 1952, Kelsen devoted himself to international law and published during the period, among other works, Society and Nature, ${ }^{30}$ Peace Through Law, ${ }^{31}$ and General Theory of Law and the State. ${ }^{32}$ He also served as a legal advisor to the United Nations War Crimes Commission, with the task of preparing the legal and technical aspects for the eventual Nuremberg Tribunals. In addition, during this period, Kelsen devoted considerable attention to the nascent United Nations organization and published the monumental 900-page monograph on The Law of the United Nations. ${ }^{33}$ This work, although now outdated, went through several editions and numerous re-printings between 1950 and 1966.

After retiring from teaching in 1952, Kelsen remained highly active, publishing in that same year his seminal work, Principles of International Law. ${ }^{34}$ The following year, in 1953, he gave a third series of lectures in The Hague. In subsequent years, he served as a visiting professor at a number of institutions, including the Universities of Vienna, Copenhagen, Stockholm,

26. HANS KELSEN, REINE RECHTSLEHRE. EINLEITUNG IN DIE RECHTSWISSENSCHAFTLICHE ProblematIK, (Franz Deuticke, Leipzig und Wien 1934). For a translation of this book, see HANS KELSEN, INTRODUCTION TOPROBLEMS OFLEGAL THEORY (Bonnie Litschewski \& Stanley L. Paulson trans., Claredon Press 1996) [hereinafter PROBLEMS OF LEGAL THEORY].

27. Hans Kelsen, Law and Peace in International Relations: The Oliver WENDELL HOLMES LECTURES 1920-41 (Harvard Univ. Press 1948) (1942).

28. Roscoe Pound, Law and the Science of Law in Recent Theories, 43 YALE L. J. 525, 532 (1934).

29. PROBLEMS OF LEGAL THEORY, supra note 26 , at xvi.

30. HANS KELSEN, SOCIETY AND NATURE: A SOCIOLOGICAL INQUIRY (1943), available at http://www-bunken.tamacc.chuo-u.ac.jp/scholar/morisue/datei.htm (last visited Apr. 12, 2004).

31. Hans Kelsen, Peace Through law (1944).

32. HANS KELSEN, GENERAL THEORY OF LAW AND THE STATE (Anders Wedberg trans., 1949).

33. HaNs Kelsen, The LaW of the UnIted Nations: A CRITICal ANalysis of Its FUNDAMENTAL PROBLEMS (George W. Keeton \& Georg Schwarzenberger eds., 1950).

34. HANS KELSEN, PRINCIPLES OF INTERNATIONAL LAW (1952). 
Edinburgh, and Chicago. By 1960, he published the second, definitive edition of Reine Rechtslehre, ${ }^{35}$ a complete revision of the previous edition. Hans Kelsen died in Berkeley on April 19, 1973, leaving behind a legacy of some four hundred published works, some of which have been translated into some two dozen languages. ${ }^{36}$

Kelsen's influence on the jurisprudence of the United Nations, if "jurisprudence" is the correct term for the Orwellian corpus produced by the legal hodgepodge of overlapping conventions, commissions, committees, and other "deliberative" bodies, cannot be underestimated. In their meticulous article-by-article commentary on the sources and redaction of the U.N. Charter, Jean-Pierre Cot and Alain Pellet cite Kelsen's influence dozens of times. ${ }^{37}$ Apart from the Charter, it is the role that Kelsen's theoretical vision plays in laying the intellectual foundations for the world body's overall ideology as to the binding nature of its "consensus" that is of capital importance. ${ }^{38}$ Before considering this later subject, however, it is necessary to examine some of the basic tenets of Kelsen's legal philosophy.

In his Pure Theory of Law, Kelsen adopted the view that law is a strictly formal construct, ${ }^{39}$ without regard for questions of content. ${ }^{40}$ Kelsen was only interested in the mechanism for the production of these legal norms, their validity, and the obligations that they entailed. ${ }^{41} \mathrm{He}$ affirmed that "a definition of law, which does not determine law as a coercive act, must be rejected."42

35. HANS KeLSEN, REINE RECHTSLEHRE (1960). For an English translation, see HANS KELSEN, PURE THEORY OF LAW (Max Knight trans., 1967) [hereinafter PTL]. All subsequent citations from PURE THEORY OF LAW are from this edition, the work of a former student of its author, who personally checked the translation.

36. See generally Nicoletta Bersier Ladavac, Bibliographical Note and Biography, 9 EUR. J. INT'L L. 391 (1998), available at http://www.ejil.org/journal/Vol9/No2/index.html (last visited Mar. 25, 2004) (listing the bibliography of Kelsen's works and their translations, arranged chronologically by date of the publication of the original work).

37. Jean-PIERRE Cot \& AlaIN PELlet, La Charte des Nations Unis. COMMENTAIRE ARTICLE PAR ARTICLE (2d ed. 1985). The absence of an index of names renders the use of this remarkable reference book a bit exacting.

38. See generally Ladavac, supra note 35 . In all fairness to the remarkable figure of Hans Kelsen, it should be noted that the jurist would probably never have imagined the influence that his theories would take on as the legal ideology of a movement toward global governance, much less might approved of the consequences of that development. That being said, however, the influence is nonetheless real.

39. See generally Iain Stewart, The Critical Legal Science of Hans Kelsen, 17 J.L. \& Soc'Y 273 (1990), available at $\mathrm{http}: / / \mathrm{www}$. law.mq.edu.au/HTML/staff/istewart/JLSKelsen.doc (last visited Apr. 12, 2004). Although Kelsen and some of his disciples resented the characterization of his "pure theory" as "formal," a more dispassionate analysis of his thought permits no other conclusion. Id.

40. PTL, supra note 34 , at 53 . "Since the law regulates the procedure by which it is itself created, one might distinguish this legally regulated procedure as legal form from the legal content established by the procedure, and speak of a legally irrelevant legal content." Id.

41. Id.

42. Id. at 54. 
This reductionism, Kelsen reckoned, was the necessary price to pay in order to achieve a legal theory of scientifically irreproachable purity: ${ }^{43}$

The obvious statement that the object of the science of law is the law includes the less obvious statement that the object of the science of law is legal norms, but human behavior only to the extent that it is determined by legal norms as condition or consequence, in other words, to the extent that human behavior is the content of legal norms. Interhuman relations are objects of the science of law as legal relations only, that is, as relations constituted by legal norms. The science of law endeavors to comprehend its object "legally," namely from the viewpoint of the law. To comprehend something legally means to comprehend something as law, that is, as legal norm or as the content of a legal norm-as determined by a legal norm. ${ }^{44}$

In this reductionist vision, the question of the norm becomes central, because "[t]hose norms, then, which have the character of legal norms and which make certain acts legal or illegal are the objects of the science of law." ${ }^{\prime 4}$

43. PROBlems of Legal THEORY, supra note 27 , at 1 . This preoccupation with vindicating the law as a "science" (Wissenschaft) and overcoming the tension between science and historicity, between "is" and "ought," introduced by Kant, and proposing a "unified science" characterized Kelsen's endeavors from the beginning. Id. at 15. See also Stewart, supra note 38. As Kelsen acknowledged in the preface to the first edition of Reine Rechtslehre in 1934:

It is more than two decades since I undertook the development of a pure theory of law, that is, a theory of law purified of all political ideology and all naturalscientific elements and conscious of its particular character because conscious of the particular laws governing its object. Right from the start, therefore, my aim was to raise jurisprudence, which openly or covertly was almost completely wrapped up in legal-political argumentation [Raisonnement], to the level of a genuine science, a science of the mind [Geistes-Wissenschaft].

Id. at iii. Editor's note: This is the author's translation.

44. PTL, supra note 34, at 70.

45. Id. at 4. Kelsen provides that '[b]y 'norm' we mean that something ought to be or ought to happen." Id. He further explains:

To say that the behavior of an individual is commanded by an objectively valid norm amounts to the same as saying the individual is obliged to behave in this way. If the individual behaves as the norm commands he fulfills his obligation-he obeys the norm; if he behaves in the opposite way, he "violates" the norm-he violates his obligation.

Id. at 15. "The norm that is regarded as objectively valid, functions as a standard of value applied to actual behavior." Id. at 17 . 
None of the classical questions of "first principles" are permitted in this schema. Kelsen states that " $[t]$ he object of a scientific theory of value can only be norms enacted by human will and values constituted by these norms." ${ }^{, 46}$

What distinguishes the legal order from other social orders (economic, religious, cultural, etc.) is its monopoly on coercion. ${ }^{47}$ This requires strong judicial and executive organs. ${ }^{48}$ It should be recalled, however, that in contrast with older philosophies of law such as the classical formulation of St. Thomas Aquinas of law ("id quod iustum est") as an ideal justice based on the divine will or Montesquieu's more modern definition of law as the necessary relations flowing from the nature of things as revealed by reason ${ }^{49}$ in Kelsen's system, the actions that government agents may compel do not derive their objective validity "from the factual act, that is to say, from an is, but again from a norm authorizing this act, that is to say, from an ought." 50

It is this context, Kelsen added that the "[n]orms according to which men ought to behave in a certain way can also be created by custom." 51 He explained that "[i]f men who socially live together behave for some time and under the same circumstances in the same way, then a tendency-that is, psychologically, a will-comes into existence within the men to behave as the members of the group habitually do."52 This, then, becomes the basis for the importance that, in the ambiance of the United Nations and its hangers-on in the NGOs, is attributed to the "international consensus" as the expression of the "general will" of the world; with neither content nor any objective outside point of reference, judges will have to fill the void with something. As Posner has observed, Kelsen advised the judge to use "ideology" to "create the specific legal norms needed for deciding cases not ruled by preexisting law." 53

The rapid expansion of claims of jurisdiction for alleged crimes against humanity is an example of how the two distinct juridical notions, custom and consensus, have been intertwined to achieve an ideologically-desired outcome, irrespective of the actual law on the books. A case on point is the arrest of the

46. PTL, supra note 34 , at 18 . He also states, "[a] norm, however, cannot be either true or untrue, but only valid or not valid." Id. at 19 .

47. Id. at 34. Kelsen provides, "The decisive criterion is the element of force-that means that the act prescribed by the order as a consequence of socially detrimental facts ought to be executed even against the will of the individual and, if he resists, by physical force." Id.

48. Id. at 37. Kelsen states, "Collective security reaches its highest degree when the legal order installs law courts with compulsory jurisdiction and central executive organs whose coercive means are so effective that resistance ordinarily is hopeless." Id.

49. John Guegen, Beyond Legal Positivism and Legal Naturalism: A Lesson from St. Thomas Aquinas, in 1 LAW AND PHILOSOPHY: THE PRACTICE OF THEORY. ESSAYS IN HONOR OF GEORGE ANASTAPLO, 258-71 (John A. Murley et al. eds., 1992).

50. PTL, supra note 34 , at 9.

51. Id.

52. Id.

53. RICHARD A. POSNER, LAW, PRAGMATISM, AND DEMOCRACY 268 (2003) (interpreting the complex argument of PTL contained in pp.104-06). 
former Chilean President, General Augusto Pinochet, in Great Britain. ${ }^{54}$ Regardless of one's views on the former military ruler and the actions of his regime, particularly during the period immediately after it took power in 1973, the facts of the case are not disputed. On September 21, 1998, the former head of state, then a senator-for-life under the provisions of the Chilean Constitution, entered Great Britain using a diplomatic passport. On October 9, he underwent surgery in a London hospital for back pain. A week later, while recovering in a hospital on October 16, he was awakened by Scotland Yard agents serving him with an arrest warrant issued by a Spanish magistrate who was investigating the deaths of Spanish nationals in the wake of the General's seizure of power in $1973 .{ }^{55}$ The case subsequently dragged on until March 2, 2000 , when the British Foreign Office decided to free the eighty-four year old Pinochet on humanitarian grounds, citing his failing health.

Also clear in the case are the international statutory and customary laws on the matter. International law confers sovereign immunity on General Pinochet for his official actions while head of state - an immunity correctly recognized by Lord Chief Justice Thomas Bingham in his original ruling of October 28, $1998,{ }^{56}$ before the politicization of the case; the Vienna Convention on Diplomatic Relations, ${ }^{57}$ to which both Great Britain and Chile adhere, is clear on the immunities enjoyed by holders of diplomatic passports, including the former Chilean President who was traveling on one. ${ }^{58}$ This immunity can only be waived by the State issuing the passport, ${ }^{59}$ in this case Chile, which formally protested the former Chilean President's detention on

54. See generally Justice Frank Sullivan, Jr., A Separation of Powers Perspective on Pinochet, 14 IND. INT'L \& COMP. L. REV. 409.

55. It should be noted that the magistrate in question, Baltazar Garzón, has carved himself a reputation for harassing high-profile "defendants." Since his failure to get custody of General Augosto Pinochet, he has attempted, using a variety of international legal instruments and ad hoc juridical justifications, to have detained Italian Prime Minister Silvio Berlusconi, former U.S. Secretary of State Henry Kissinger, and amnestied ex-members of the former military government in Argentine. John Carlin, Spain's Man of Law With Cojones of Steel: General Pinochet, Henry Kissinger and the Bali Bombers are the Big Guys Judge Baltazar Garzon Goes After. But He is Not Without Enemies of His Own, NEwS STATEMENT (London), Oct. 28, 2002, available at $\mathrm{http} / / \mathrm{www}$.findarticles.com/cf_dls/m0FQP/4611_131/94509907/p1/article.jhtml (last visited Mar. 25, 2004). He has also investigated former Peruvian President Alberto Fujimori, now living in exile in Japan. One cannot help but note a certain political bias in the subjects he has selected for his "judicial" inquiries.

56. In re an Application for a Writ of Habeas Corpus ad Subjiciendum re: Auguto Pinochet Ugate, 38 I.L.M. 68 (Q.B. Div'l Ct. 1998).

57. Vienna Convention on Diplomatic Relations, adopted Apr. 18, 1961, 23 U.S.T. 3227, 500 U.N.T.S. 96, available at http://www.un.org/law/ilc/texts/diplomat.htm (last visited Feb. $27,2004)$. Originally signed by sixty States plus the Holy See, presently 178 States have ratified it. Id.

58. Id. art. 29. It states, "The person of a diplomatic agent shall be inviolable. He shall not be liable to any form of arrest or detention. The receiving State shall treat him with due respect and shall take all appropriate steps to prevent any attack on his person, freedom or dignity." Id.

59. Id. art. 32. 
October 17, the day after his arrest. Furthermore, the immunity also applies if the holder of the passport travels through another country. ${ }^{60}$

In the case of Great Britain, its treaty obligations required it respect the immunities that the Chilean government had seen fit to accord General Pinochet when the latter issued him a diplomatic passport. If the British authorities found the comings and goings of the former military ruler objectionable, they had the right to refuse him passage, but once they had admitted him under diplomatic cover, the traditional understanding at the time was that they were obliged to respect that cover. ${ }^{61}$

However, the British government and courts, under relentless scrutiny from the media and pressure groups, discovered a new "consensus" - albeit one never codified by the same solemnities as the Vienna Convention - that permitted it to justify a total innovation: the arrest of the holder of a diplomatic passport with a view at deporting him to a third country. ${ }^{62}$ Thus, in one fell swoop, a new lex gentium was inaugurated based on a "consensus" of "world opinion." Kelsen's theory anticipated such a move:

Traditional science of law assumes that opinio necessitatis is an essential component of the facts of custom. That is to say that the acts which constitute the custom must take place in the belief that they ought to take place. But this opinion presupposes an individual or collective act of will whose subjective meaning is that one ought to behave according to custom. If customary law, like statutory law, is positive law, then there must be an individual or collective act of will

60. Id. art. 40. It provides, "If a diplomatic agent passes through or is in the territory of a third State, which has granted him a passport visa if such visa was necessary . . , the third State shall accord him inviolability and such other immunities as may be required to ensure his transit or return." Id.

61. Cf. EILEEN DENZA, DiPlomatic LAW, A COMMENTARY ON THE VIENNA CONVENTION ON DiPLOMATIC RELATIONS (2d ed. 1998).

62. Even if one accepts the somewhat far-fetched claim by the Spanish judge Baltazar Garzon that the actions carried out by the regime of then-President Augusto Pinochet amounted to the crime of "genocide" as defined by the 1948 United Nations Convention for the Prevention and Punishment of Genocide, there remains the fact that the British Parliament, when it ratified that international agreement with the passage of the United Kingdom Genocide Act of 1969, deliberately omitted article IV, which lifts sovereign immunity. See Sullivan, supra note 53 at 425-26. Hence, even if General Pinochet were guilty, there was no British statutory authority duly passed according to the Britain's unwritten constitution on which to actually hold and extradite him. See id. And even if one accepted the legal reasoning adopted by the Judiciary Committee of the British House of Lords in its November 25, 1998, appellate opinion overturning the Lord Chief Justice's ruling that "international law has made it plain that certain types of conduct ... are not acceptable conduct on the part of anyone," it is a still a leap from that conclusion to endowing a magistrate with domestic jurisdiction in another country with the enforcing that principle on the national of still another country. See Henry A. Kissinger, The Pitfalls of Universal Jurisdiction, FOREIGN AFF., 86-96 (July-Aug. 2001). 
whose subjective meaning is the "ought"-that is interpreted as objectively valid norm, as customary law. ${ }^{63}$

What is at stake here is not the hallowed custom that is a secondary source of law in civil law societies, much less the common law of societies that follow Anglo-Saxon jurisprudence. Rather, what Kelsen proposes is a sociological circle wherein the norm ought to reflect the conduct of the members of the group. This "consensus" is interpreted to be the expression of a "general will," that is then obligatory on all as a norm:

At first the subjective meaning of the acts that constitute the custom is not an ought. But later, when these acts have existed for some time, the idea arises in the individual member that he ought to behave in the manner in which the other members customarily behave, and at the same time the will arises that the other members ought to behave in that same way. If one member of the group does not behave in the manner in which the other members customarily behave, then his behavior will be disapproved by the others, as contrary to their will. In this way the custom becomes the expression of a collective will whose subjective meaning is an ought. $^{64}$

Even as he referred to the sociological nature of the process for the formation of norms, Kelsen rejected any recourse to the use of "sociology" in $s e-$ or what might today be referred to as the "social sciences"-in adjudicating the contents of the norms, in order to preserve his "pure theory" from contamination by the use of tools other than logic. ${ }^{65}$

Over the long run, this approach tends to generalize customary practices never formally subject to the usual give-and-take of legislative debate whereby a constitutional consent is normally given, and arrives at canonizing a "consensus" that obliges all to submit to it. It is, in short, precisely the incremental "consensus"-driven legal approach of the U.N. organs, which adhere to a corollary construct of legal order seen as a pyramid-like structure:

Because of the dynamic character of law, a norm is valid because, and to the extent that, it had created in a certain way, that is in a way determined by another norm, therefore that other norm is the immediate reason for the validity of the new norm. The relationship between the norm that regulates the

63. PTL, supra note 34, at 225.

64. Id. at 9.

65. See Renato Treves, Hans Kelsen et la sociologie du droit, DROIT ET SOCIÉTÉ 1, 15-25 (1985) (discussing Kelsen's ideas regarding the sociology of justice). 
creation of another norm and that norm created in conformity with the former can be metaphorically presented as a relationship of super- and subordination. The norm which regulates the creation of another norm is the higher, the norm created in conformity with the former is the lower one. The legal order is not a system of coordinated norms of equal level, but a hierarchy of different levels of legal norms. Its unity is brought about by the connection that results from the fact that a validity of a norm, created according to another norm, rests on that other norm, whose creation, in turn, is determined by a third one. This is a regression that ultimately ends up in the presupposed basic norm [Grundnorm]. This basic norm, therefore, is the highest reason for the validity of the norms, one created in conformity with another, thus forming a legal order in its hierarchical structure. ${ }^{66}$

This passage, needless to say, eerily presages the actual modus operandi of the various specialized U.N. organs and the NGOs associated with the fields of competence of those official agencies. The evolution of the situation leading up to the present furor over America's alleged "unilateralism" on environmental issues neatly illustrates the point. ${ }^{67}$ In the late 1960 s, the United Nations Economic and Social Council decided to convene an international conference on the environment. After several years of preparatory meetings and the establishment of various panels of experts, the United Nations Conference on the Human Environment met in Stockholm on June 5, 1972 for eleven days. The chief accomplishments of the Stockholm Conference, as it came to be known, were the publication of a "Stockholm Declaration" containing some twenty-six "principles of common conviction" and a call for the follow-up conference. As it turns out, this conference took two decades to organize, although during the interim, a U.N. Commission on Environment and Development was constituted. In 1987, this body, subsequently known as the Brundtland Commission after its president, former Norwegian prime minister Go Harlem Brundtland, issued a report calling for the establishment of an "international charter for sustainable development." This task was taken up by the United Nations Conference on Environment and Development that, meeting in Rio de Janeiro June 3-14, 1992, reaffirmed the "Stockholm

66. PTL, supra note 34 , at 221-22.

67. For a discussion of the scientific controversies surrounding the issues involved in the international environmental debate, see Jack M. Hollander, Rushing to Judgment, WusON Q., 64-77 (Spring 2003) and V. Ramanathan \& Tim P. Barnett, Experimenting with the Earth, WILSON Q., 78-84 (Spring 2003). For additional background information on Kyoto and the United State's role, see generally Micheal Betsill, Environmental NGOs Meet the Sovereign State: The Kyoto Protocol Negotiations on Global Climate Change 13 CoLo. J. INT'L ENVTL. L. \& POL'Y 49; Anita Margrethe Halvorssen, Climate Change Treaties-New Developments at the Buenos Aires Conference 1998 COLO. J. INT'L ENVTL L. Y.B. 1. 
Declaration" and issued its own "Rio Declaration" with twenty-seven principles and a wish-list entitled "Agenda 21." Just before the conference in Rio de Janeiro, the "United Nations Framework Convention on Climate Change" was signed in New York on May 9, 1992. The much-controverted Kyoto Protocol of December 11, 1997 is officially an instrument of implementation for this earlier convention.

The Rio de Janeiro meeting was followed by two ministerial-level conferences in Nairobi (1997) and Malmo (2000) which, in turn, led to the World Summit on Sustainable Development in Johannesburg (August 26September 4, 2002). The meeting issued a thirty-seven point political "Declaration," document is a detailed regulatory undertaking to carry out the objectives of not only the Johannesburg conference, but also all of its predecessors. Its preamble deserves to be quoted in its entirety given the remarkable similarity to the process outlined by Kelsen with one norm founded on little else but the previous norm:

\begin{abstract}
The United Nations Conference on Environment and Development [UNCED], held in Rio de Janeiro in 1992, provided the fundamental principles and the programme of action for achieving sustainable development. We strongly reaffirm our commitment to the Rio principles, the full implementation of Agenda 21 and the Programme for the Further Implementation of Agenda 21. We also commit ourselves to achieving the internationally agreed development goals, including those
\end{abstract}

68. World Summit on Sustainable Development, Declaration on Sustainable Development (17th Plenary Session, Sept. 4, 2002), available at www.un.org/esa/sustdev/documents/ WSSD_POI_PD/English/POI_PD.htm (last visited Mar. 31, 2004).

69. World Summit on Sustainable Development, Plan of Implementation, available at http://www.un.org/esa/sustdev/documents/WSSD_POI_PD/English/POIChapter1.htm (last visited Mar. 31, 2004). The document contains, among others, the provision that:

Good governance at the international level is fundamental for achieving sustainable development. In order to ensure a dynamic and enabling international economic environment, it is important to promote global economic governance.

A vibrant and effective United Nations system is fundamental to the promotion of international cooperation for sustainable development and to a global economic system that works for all. To this effect, a firm commitment to the ideals of the United Nations, the principles of international law and those enshrined in the Charter of the United Nations, as well as to strengthening the United Nations system and other multilateral institutions and promoting the improvement of their operations, is essential. States should also fulfill their commitment to negotiate and finalize as soon as possible a United Nations convention.

Id. at n. 141-42.

Not only is global governance advocated, but also the text goes beyond the principle pacta sunt servanda, that nation-states should observe the obligations they assume, to admonish states to take on the obligations! 
contained in the United Nations Millennium Declaration and in the outcomes of the major United Nations conferences and international agreements since 1992.

The present plan of implementation will further build on the achievements made since UNCED and expedite the realization of the remaining goals. ${ }^{70}$

The concerning feature of this pyramid construction is that the juridical norm does not oblige by reason of consent, much less by the inherently compelling nature of the truth claims of its content or their relationship to the demands of justice, as understood by classical philosophers and jurists. For Kelsen, "there are no mala in se, but only mala prohibita,"71 that is, no crimes that are wrong in themselves rather than wrong simply by being declared wrong by the law. Thus, a norm is rendered obligatory by reason of its logical coherence with the normative scheme for the production of juridical norms. ${ }^{72}$

Once he had established that law was a pyramid-like system of norms, Kelsen was confronted with the question: "What constitutes the unity of a multitude of norms?" Closely tied to this question is another one: "Why is a norm valid, what is the reason for its validity?"74 The answer Kelsen gives to these queries is almost Kantian:

The norm which represents the reason for the validity of another norm is called, as we have said, the "higher" norm. But the search for the reason of a norm's validity cannot go on indefinitely like the search for cause and effect. It must end with a norm which, as the last and highest, is presupposed. It must be presupposed, because it cannot be "posited," that is to say: created, by an authority whose competence would have to rest on a still higher norm. This final

70. Id. at n. $1-2$

71. PTL, supra note 34 , at 112.

72. As Kelsen noted:

The norm system that presents itself as a legal order has essentially a dynamic character. A legal norm is not valid because it has a certain content, that is, because its content is logically deducible from a presupposed basic norm [Grundnorm], but because it was created in a certain way ultimately in a way determined by a presupposed basic norm. For this reason alone does the legal norm belong to the legal order whose norms are created to this basic norm. Therefore any kind of content might be law. There is no human behavior which, as such, is excluded from being the content of a legal norm. The validity of a legal norm may not be denied for being (in its content) in conflict with another norm that does not belong to the legal order whose basic norm is the reason for Id. at 198. the validity of the norm in question.

73. Id. at 193.

74. Id. 
norm's validity cannot be derived from a higher norm, the reason for its validity cannot be questioned .... All norms whose validity can be traced back to one and the same basic norm [Grundnorm] constitute a system of norms, a normative order. The basic norm is the common source for the validity of all norms that belong to the same order-it is their common reason of validity. ${ }^{75}$

Therefore a given norm is binding by reason of the validity conferred on it by a higher norm. It must be obeyed, and any disobedience must be punished. Kelsen added that this normative system is the basis for the state since "as a political organization, the state is a legal order," specifically a "relatively centralized legal order." 76 He went on to define the state as "a corporation, that is, a community constituted by a normative order which institutes organs directly or indirectly .... The order constituting this community is the legal order, designated as national legal order in contradistinction to the international legal order." 77

While the question of the basic norm (Grundnorm) was formulated in reference to the state, it also enters into play both in Kelsen's philosophy of law and for purposes of the present inquiry into the legal ideology driving the U.N.'s ambitions to governance in questions regarding the relationship of the law of the nation-state and international law. There are two schools of thought in this regard. The classical view, since the Peace of Westphalia (1644) ended the Wars of Religion in Europe, has been that a norm of international law is binding on a given sovereign state only if the government of that state, through the means provided for in its constitution, has explicitly recognized that international norm. ${ }^{78}$ According to this view, international law constitutes "only a part of the national legal order, regarded as sovereign" and "the validity of the national legal order is the basic norm referring to the effective constitution" of the state. ${ }^{79}$

Kelsen, however, proposed a revolutionary view.

International law is not regarded as part of the national legal order, but as a sovereign legal order, superordinated to all national legal orders, limiting them in their spheres of

75. Id. at 194-95.

76. Id. at 286.

77. PTL, supra note 34, at 290.

78. See David Fagelson, Two Concepts of Sovereignty: From Westphalia to the Law of Peoples?, 38 INT'L POL. 499 (2001) (discussing the development of the Westphalian idea of sovereignty as well as the incremental assaults on it in recent times). For a different reading of the same history with a relatively sympathetic treatment of recent developments, see DANIEL PHILPOTT, REVOLUTIONS IN SOVEREIGNTY: HOW IDEAS SHAPED MODERN INTERNATIONAL RELATIONS 73-105 (2001).

79. PTL, supra note 34 , at 214. 
validity; in other words, one does not assume the primacy of the national legal orders, but the primacy of the international legal order. The latter does, in fact, contain a norm that represents the reason for the validity of the individual national legal orders. ${ }^{80}$

Kelsen explained his view by noting that international law "consists of norms which originally were created by custom, which is by acts of the national states or, more correctly formulated, by the state organs authorized by national legal orders to regulate interstate relations." ${ }^{81}$ These norms are "general" in that they create rights and obligations for all states. Among these norms, Kelsen cited the principle "pacta sunt servanda" ("pacts should be respected"), whereby individual states regulate by treaty the mutual relations between their organs and subjects. The authorized organs of the states, in Kelsen's terms, agree in the creation of norms whereby rights are created and obligations are imposed between them. Kelsen, however, noted that international law created by such bilateral treaties "does not have general but only particular character" since "its norms are not valid for all states, but only for two or a larger or smaller group of states," thus constituting only "partial communities." Consequently,

[p]articular international law created by treaties and general international customary law are not to be regarded as norms on the same level. Since the basis of the one group of norms is a norm that is part of the other group, the two have a relation of a higher and a lower level in a hierarchy. ${ }^{83}$

According to Kelsen, beyond these two lay a third level. ${ }^{84}$ In the formation of national law, the preeminent role traditionally attributed to custom is extended to the creation of international law. In other words, if established constitutional convention-the active "consent of the governed"

80. Id.

81. Id. at 323 .

82. Id. at 324 .

83. Id.

84. Kelsen states:

If we consider also the legal norms created by international courts and by other international organs, established by treaties, a third level appears in the structure of international law. For the function of such an organ is itself based on an international treaty, that is to say, on a norm of the second level of international law. Since this second level, that is the international law created by international treaties, rests upon the norm of general customary international law (the highest level), the presupposed basic norm [Grundnorm] of international law must be a norm which establishes custom constituted by mutual behavior of states as lawcreating fact. 
of American Founding Fathers - is the foundation of the national legal system, the passive "consensus" of the "community of nations" is the basis for international law. International organizations, their functionaries and international tribunals are charged with articulating what that "consensus" consists of specifically. Writing in the late 1950s, Kelsen admitted that his envisioned international legal order was only in its infancy, but he predicted its potential for growth.

This vision of international law necessarily entails the subordination of national legal systems to a global system, that is, the transfer of sovereignty from national states to the overarching structure of a supranational federation, if not the total absorption of that sovereignty by a single global "super state" that would be sole subject of sovereignty. ${ }^{85}$

Writing long before "globalization" became a catch phrase to describe an ill-defined phenomenon, ${ }^{86}$ Kelsen argued that this evolution towards a single global order was a logical necessity given the identification of the state and its legal system. The international legal system was thus conceived as an instrument for the unification and centralization of a global society that would be characterized less by "inter-nationalism" than by "supra-nationalism." ${ }^{87}$

This is not only the monopolization of sovereignty by a super-state but, moreover, an inversion of the traditional principal of subsidiarity. In this scheme, it is not the super-state that plays a complementary role vis-à-vis

85. Kelsen elaborates:

International law is "law," if it is a coercive order, that is to say, a set of norms regulating human behavior by attaching certain coercive acts (sanctions) as consequences to certain facts, as delicts, determined by this order as conditions, and if, therefore, it can be described in sentences which-in contradistinction to Id. at 320 .

legal norms - may be called as "rules of law."

86. Pundits still differ as to the specifics of the "globalization" phenomenon. Some, such as New York Times columnist Thomas Friedman, see it as a "dynamic ongoing process," driven by economics but having a cultural dimension. See THOMAS L. FRIEDMAN, THE LEXUS AND THE OLIVE TREE 3-16 (Anchor Books rev. ed 2000). Others, like British philosopher Roger Scruton, see it in terms of the transfer of power to global organizations. See ROGER SCRUTON, THE WEST AND THE REST: GLOBALIZATION AND THE TERRORIST THREAT (2002). In his book, Scruton writes:

Globalization does not mean merely the expansion of communications, contacts, and trade across the globe. It means the transfer of social, economic, political, and juridical power to global organizations, by which I mean organizations that are located in no particular sovereign jurisdiction, and governed by no particular territorial law. ... These organizations pose a new kind of threat to the only form of sovereignty that has brought lasting (albeit local) peace to our planet. Id. at 127.

87. PTL, supra note 34 , at 328.

The entire legally technical movement, as outlined here, has - in the last analysis - the tendency to blur the border line between international and national law, so that as the ultimate goal of the legal development directed toward increasing centralization, appears the organizational unity of a universal legal community, that is, the emergence of a world state. 
individual states, but rather the latter that are subsidiaries of the former. If the point of departure is assumed, as under Kelsen's philosophy, to be that the validity of the international legal system, then national legal systems must base their own validity on their submission to a supranational system: "International law must be conceived . . . as a total legal order comprising all national legal systems as partial orders, and superior to all of them." 88

Consequently, if one accepts this line of reasoning-and recognition of this point explains the moral indignation with which the withdrawal of the American signature from the Rome Statute of the International Criminal Court was greeted-international tribunals must be able to override national judicial systems because the judges of these international assizes, in collaboration with international functionaries, must affirm the superiority of global governance over national sovereignty. ${ }^{89}$

It does not require a conspiratorial mindset to note that the instruments for vindicating these claims are being put into place with the establishment of the International Criminal Court. In a break with centuries-old principles of the lex gentium, the Rome Statute extends the Court's jurisdiction even to citizens of countries that are either not signatories or signatories who have not ratified the treaty. ${ }^{90}$ In addition to the International Criminal Court, to which

88. Id. at 333 .

89. As Kelsen expounds:

[I]t becomes manifest that what is regarded as conflict between the norms of international law and the norms of national law is not a conflict of norms at all. ... It has been shown before that a norm contrary to a norm does not mean a conflict between a norm of a lower level and a norm of a higher level, but only means that the validity of the lower may be abolished or the responsible organ may be punished.

Id. at 330 .

90. Even for citizens of states that have ratified the Rome Statute and, consequently, undeniably subject legally to its jurisdiction, the International Criminal Court's (ICC) structure should be of little comfort. As an institution, the Court is police, prosecutor, judge, jury, and jailer, all these functions being performed by its staff without regard for any separation of powers. Additionally, there are no provisions for appeal from its judgments. For a general critique, see Lee A. Casey \& David B. Rivkin, Jr., The International Criminal Court vs. the American People, Heritage Found., Feb. 5, 1999, at http://www.heritage.org/Research/ InternationalOrganizations/BG1249.cfm (last visited Feb. 24, 2004). The International Criminal Court's structure is of little comfort, even for citizens of states that have ratified the Rome Statute, because they are undeniably legally subject to its jurisdiction. Id. For another critical appraisal of the ICC, including its statutory conflicts with the United States Constitution, see Gary T. Dempsey, Reasonable Doubt: The Case against the Proposed International Criminal Court, Cato Institute, July 16, 1998, at http://www.cato.org/pubs/pas/pa-311.html (last visited Feb. 25, 2004) (appraising the ICC, including its statutory conflicts with the Untied States Constitution). On the question of the judicial independence of the ICC, whose judges, once selected by a political process, will have extraordinary discretionary authority, see Silvia de Bertodano, Judicial Independence in the International Criminal Court, 15 LEIDEN J. INT'L L. 409 (2002). The judicial independence of the ICC, once selected by a political process, will have extraordinary discretionary authority. Id.

Even proponents of international assizes admit the shortcomings, to put it mildly, of recent experiences. See David Tolbert, The Evolving Architecture of International Law: The 
International Criminal Tribunal for the Former Yugoslavia: Unforeseen Successes and Foreseeable Shortcomings, FLETCHER F. WORLD AFF. J., Fall 2002, at 7. See also Victor Peskin, Conflicts of Justice: An Analysis of the Role of the International Criminal Tribunal for Rwanda, 6 Int'l Peacekeeping 128 (2000). See Victor Peskin, Rwandan Ghosts, LeGAL AFF, Sept.-Oct. 2002, at 21, available at http://www.legalaffairs.org/issues/September-October2002/feature_peskin_sepoct2002.html (last visited Feb. 24, 2004). An observer's journal of the difficulties encountered by the International Criminal Tribunal for Rwanda includes some disturbing anecdotal accounts. Id. Serious questions of procedural safeguards for the rights of defendants before the International Criminal Tribunal for the Former Yugoslavia are raised in Renee C. Pruitt, Guilt by Majority in the International Criminal Tribunal for the Former Yugoslavia: Does this Meet the Standard of Proof: Beyond Reasonable Doubt? 10 LEIDEN J. INT'L L. 557 (1997).

The personal diplomatic experience of the present author while dealing with the Special Court for Sierra Leone during its formative period of 2001-2002 confirms in his mind some of the myriad of systematic procedural difficulties and lack of legal guarantees associated with these international tribunals. The Special Court is not directly a United Nations organ but rather an independent international institution with its own special status granted to it by the U.N. and the government of Sierra Leone to prosecute alleged war crimes that occurred during the brutal civil conflict in West Africa. The Special Court has jurisdiction only for offenses alleged to have occurred after November 30, 1996. S.C. Res. 1315, U.N. SCOR, 55th Sess., 4186th mtg., U.N. Doc S/RES/ 1315 (Aug. 2000), available at http://ods-ddsny.un.org/doc/UNDOC/GEN/N00/605/32/PDF/N0060532.pdf?OpenElement (last visited Feb. 42, 2004) [hereinafter Resolution 1315]. The Special Court, authorized by Resolution 1315 in August 2000, took shape when the U.N. Secretariat and the Sierra Leone government agreed on a twenty-three article "status agreement" and a twenty-five article statute for the tribunal on January 16, 2002. This took place, despite the fact that several potential principal defendants, including the Revolutionary United Front (RUF) leader, Foday Sankoh, had been in custody since early 2000 . The legislation for the tribunal was passed by the parliament of Sierra Leone on March 19, 2002 and signed by President Ahmed Tejan Kabbah on March 29, 2002. On April 17, 2002, U.N. Secretary General Kofi A. Annan appointed David M. Crane, a former attorney with the U.S. Department of Defense, as the chief prosecutor for the Court and Briton Robin Vincent as its registrar. For the appointment of judges for the three-member trial chamber and the five-member appeal chamber, the statute called for the Sierra Leonian government to appoint one trial judge and two appeals judges and the U.N. Secretary General to appoint two trial judges and three appeals judges and the two parties to agree on two alternate judges. The appointment of judges was delayed until July 29, 2002.

Since then, the Court has been busy with many things, although one might be excused for asking if proceeding to an expeditious trial of the defendants is one of them. Crane, a wellrespected international lawyer, has traveled extensively giving speeches at various international and national conferences and issued statements to commemorate such occasions as International Women's Day. However, Crane only managed to indict five highly suspect defendants. Two other men were indicted, but one was killed shortly thereafter in Liberia while the other was at large on March 10, 2003. Some of the judges appointed have only been in Sierra Leone (the tribunal is to sit in the capital of Freetown) on the occasion of their swearing-in on December 2,2002 . The five indicted defendants in custody were transferred to the custody of the Court on March 21, 2003. It took another two weeks, until April 7,2003, for the administrators of the tribunal to come up with a statute for their imprisonment that regulated details of their incarceration, including the four-day rotation of the menu. As yet, no dates have been set for the initial hearing, much less for trials. A visit to the website of the tribunal reveals that as late as May 1, 2003, several significant posts had not yet been filled, most notably that of defense counsel. See Special Court for Sierra Leone, at www.sc-sl.org (last visited Apr. 12, 2004). The lead defendant, Foday Sankoh, died in custody on July 27, 2003, after waiting three years for proceedings against him to commence.

The entire episode has Kafka-like tones, which does not seem to have concerned 
some attention has been focused in recent years, there are other examples of the creeping expansionism of the global legal system. To cite, by way of illustration, but one other example, there was the creation, by a fifty to three vote of the United Nations Human Rights Commission on April 26, 2000, of a whole new office, that of the "Special Representative of the SecretaryGeneral for Human Rights Defenders,",9l charged with enforcement of an illdefined categories of "rights" (and their promoters, hence the job title) described as "universally recognized.",92 This development was, once again, postulated by Kelsen as part of the subsuming of national legal systems into a unitary international system. ${ }^{93}$

many of those associated with the process. The Special Court's statute states that it will rely on the jurisprudence of the appeals chambers of the International Criminal Tribunal for the former Yugoslavia and the International Criminal Tribunal for Rwanda to create its procedural law, although they are themselves both "works in progress." The defendants, as reprehensible as their alleged actions were, have now been held for over three years, and there is no clear indication of when their cases will be adjudicated. Even when it comes to judgment, the statute of the Court provides for a determination of guilt by a majority vote (i.e., two out of three judges of the trial bench (art. 18)), hardly much protection for the accused. The Special Court, meanwhile, is looking at expanding its reach and has issued an arrest order for Charles Ghankay Taylor, until last year president of neighboring Liberia, citing his role in the Sierra Leonean conflict.

Catherine Cissé, Le Tribunal spécial pour la Sierra Leone, 4 INT'L LAW FORUM DU DROIT INT'L 3, 7-11 (2002). Cissé chronicles the discussion surrounding the establishment and early development of the Special Court for Sierra Leone.

91. This office is to be distinguished from that of the "High Commissioner for Human Rights," created by the United Nations General Assembly in 1993.

92. See Declaration on the Rights and Responsibilities of Individuals, Groups and Organs of Society to Promote and Protect Universally Recognized Human Rights and Fundamental Freedoms, G.A. Res. 53/144, U.N. GAOR, 53rd Sess., U.N. Doc A/RES/53/144 (1999) (calling upon each state to implement such varied list of ambiguously defined rights). The notorious homosexual pedophile group, the North American Man/Boy Love Association (NAMBLA), has used its provisions obliging states to respect "rights of association" in its fight against U.S. prosecutors.

93. See PTL, supra note 34 , at 336-37.

If we start from the validity of international law which does not require recognition by the state, then the mentioned constitutional provision [of adherence to and ratification of the international norm by the state] does not mean that it puts into force international law for the state concerned, but merely that international law-by general clause - is transformed into national law. Such transformation is needed, if the organs of the state, especially its tribunals, are only authorized (by the constitution) to apply national law; they can, therefore, apply international law only if its content has assumed the form of national law (statute, ordinance) that is, if it has been transformed into national law. If, in default of transformation, a norm of international law cannot be applied in a concrete case, then (if we start from the validity of international law) this does not mean that this norm of international law is not valid for the state; it only means that, if it is not applied and therefore international law is violated by the state's behavior, the state exposes itself to the sanctions prescribed by international law.

Id. 
In fact, the consequence of Kelsen's legal philosophy is that the national state's existence is dependent upon its adherence to the international juridical system.

The national state, then, in its legal existence appears determined in all directions by international law, that is, as a legal order delegated by international law in its validity and sphere of validity. Only the international legal order, not the national legal order, is sovereign. If national legal orders or the legal communities constituted by them, i.e., the states, are denoted as "sovereign," this merely means that they are subject only to the international legal order. ${ }^{94}$

This highlights one of the basic consequences of Kelsen's theory: that there exists no difference in the nature of national law and international law. ${ }^{95}$ Traditionally, the jurisdiction of the national legal system was concerned with either the relationships between the state and its citizens ("public law," in the parlance of the civil law tradition) or the relationships between the citizens themselves ("private law"). The international legal system only concerned itself with relations between nation-states, international law being created through the consent of states. Underlying this was the traditional doctrine that states, being sovereign, cannot be bound by higher laws without their consent. Corollary to this principle, recognized by the Permanent Court of International Justice, the predecessor to the present-day International Court of Justice at The Hague, is that a sovereign state may lawfully do as it pleases unless it has otherwise consented to restrict itself. ${ }^{96}$

In contrast, Kelsen brought into focus the idea, now quite current in global circles, that international law is not confined to relations among states, but it can encompass all areas of human activity. In fact, an increasing quantity of international legislation now applies to private individuals, not

94. Id. at 338.

95. See François Rigaux, Hans Kelsen on International Law, 9 EUR. J. INT'L LAw 248, 325-43 (1998).

96. The Case of S.S. Lotus, (Fr. V. Turk.) P.C.I.J. Ser. A. No. 10 (1927), available at http://www.worldcourts.com/pcij/eng/cases/lotusintro.htm (last visited Mar. 2, 2004).

International law governs relations between independent States. The rules of law binding upon States therefore emanate from their own free will as expressed in conventions or by usages generally accepted as expressing principles of law and established in order to regulate relations between these co-existing independent communities or with a view to the achievement of common aims. Restrictions upon the independence of States cannot therefore be presumed.

Id. See also Anthony Clark Arend, Is Preemption Necessary?, WASH. Q., 89-103 (Spring 2003) (providing an interesting analysis, in terms of this traditional international law doctrine, of the "Bush Doctrine" of the unilateral preemptive use of force). 
merely to sovereign entities, raising a host of civil liberties questions. ${ }^{97}$ Other international agreements, such as the Convention on the Elimination of All Forms of Discrimination Against Women ${ }^{98}$ and the Convention on the Rights of the Child, ${ }^{99}$ while binding on state parties, have given rise to permanent bureaucracies charged with "monitoring" the accords and generating, without the legal process of treaty adoption and ratification, ongoing norms. ${ }^{100}$ Recently, international law considerations have even been injected into both trial and appellate courts in domestic death penalty cases in the United States. Lawyers in the United States have tried to get courts to recognize international legal standards-some of which are matters of policy to which the U.S. government has never consented-as applicable to individual defendants and enforceable against the individual American states. ${ }^{101}$

In this new order, the traditional nation-state survives as a mere shadow of its former self, much in the manner that the member states of the European Union have seen more and more of their former legislative prerogatives taken over by the Brussels-based bureaucrats of the many regulatory agencies of the European Commission. European Commission President Romano Prodi is very candid about this process. ${ }^{102}$ According to Kelsen, the advent of the

97. See, e.g., Ronald D. Rotunda, Constitutional Problems with Enforcing the Biological Weapons Convention, Cato Institute Foreign Pol'y Briefing, No. 61 (2000).

98. Convention on the Elimination of All Forms of Discrimination Against Women, adopted Dec. 18, 1979, 1249 U.N.T.S. 14, available at http://www.un.org/womenwatch/daw/ cedaw (last visited Apr. 1, 2004).

99. Convention on the Rights of the Child, adopted Nov. 20, 1989, 1577 U.N.T.S. 3, available at http://www.unhchr.ch/html/menu3/b/k2crc.htm (1989).

100. See Fact Sheet, UN Office of the High Commissioner for Human Rights, The Rights of the Child, available at http://www.unhchr.ch/html/memu6/2/fs10.htm\#ii??? (last visited Mar. 3,2004 ) (listing the ongoing activities of the United Nations Committee on the rights of the child). See also UN Economic and Social Development, Division for the Advancement of Women, General Recommendations on Reporting, available at http://www.un.org/ womenwatch/daw/cedaw/recommendations.htm (last visited Mar. 3, 2004); UN Economic and Social Development, Division for the Advancement of Women, Reporting, available at http://www.un.org/womenwatch/daw/cedaw/reporting.htm (last visited Mar. 3, 2004); Patrick F. Fagan, How U.N. Conventions on Women's and Children's Rights Undermine Family, Religion, and Sovereignty: Supplemental Material: Quotations from CRC and CEDAW Committees of the United Nations, (Feb. 5, 2001), Heritage Found., available at http://www.unhchr.ch/html/memu6/2/fs $10 . h t m \# i i$ (last visited Mar. 3, 2004) (analyzing the two conventions and their effects on both familial law and national sovereignty).

101. See Sandra Babcock, The Role of International Law in United States Death Penalty Cases, 15 LEIDEN J. INT'L L. 367, 367-87 (2002).

102. President of the European Commission Romano Prodi, Speech at the Institut d' Etudes Politiqes, Paris, France (May 29, 2001), available at http://europa.eu.int/rapid/start/cgi/ guesten.ksh?p_action.gettxt=gt\&doc=SPEECH/01/244|0|AGED\&lg=EN\&display= (last visited Feb 7, 2004). Prodi states:

The genius of the founding fathers lay in translating extremely high political ambitions . . . into a series of more specific, almost technical decision. This indirect approach made further action possible. Rapprochement took place gradually. From confrontation we moved to willingness to cooperate in the economic sphere and then on to integration. 
supranational order will leave individuals states entirely dependent upon the international system. ${ }^{103}$

Not only may the international legal system limit the sovereignty of the individual nation-states, it may even eclipse it entirely. ${ }^{104}$ Commenting on the relationship of national legal systems and European Community law with explicit reference to Kelsen's legal philosophy, one scholar has asserted that this is precisely the case already with regard to the sovereignty of the nationstates that are members of the European Union. ${ }^{105}$

Of course, the risk contained in an absolute principle whereby national legal systems must always defer to supranational systems is amply illustrated in European community laws which are often more ambiguous and general than the more precisely-defined provisions contained in the legislation of some member-states. This is a consequence of not all rights being recognized by all

Id. Citing to this success, Prodi asserted that as a consequence the, "[European] Union has a role to play in world 'governance,"' based on replicating the European experience on a global scale. Id. On the ideological foundations of the European Union and its bureaucracy, see ROLAND HUREAUX, LES HAUTEURS BÉANTES DE L'EuROPE, LA DÉRIVE IDÉOLOGIQUE DE LA CONSTRUCTION EUROPÉENNE (1999).

103. PTL, supra note 34 , at 337.

Since international law regulates the behavior of states-it must determine what is a "state" in the sense of international law, it must determine under what conditions individuals are to be regarded as the government of a state; therefore, under what conditions the coercive order under which they function is to be regarded as a valid legal order; under what conditions their acts are to be regarded as acts of state, that is, legal acts in the meaning of international law.

Id.

104. Kelsen noted this eclipsing:

Although the individual states remain competent, in principle (even under international law) to regulate everything, they retain their competence only so far as international law does not regulate a subject matter and thereby withdraws it from free regulation by national law. Under the assumption of international law as a supranational legal order, the national legal order, then, has no longer an, illimitable competence (Kompetenzhoheit).

Id. at 338.

105. See Ines Weyland, The Application of Kelsen's Theory of the Legal System to European Community Law-The Supremacy Puzzle Resolved, 21 L. \& PHIL., INT'L J. JURISPRUDENCE \& LEGAL PHIL. 1 (2002).

If the basic norm also confers law creating powers on Community constitutional organs then the supremacy principle will resolve conflicts between national and Community constitutional norms, .... The supremacy principle subordinates substantive national constitutional norms to substantive Community constitutional norms .... The relationship of subordination will result in the disapplication of the national constitutional norms in the areas falling under the competence of Community law and would afford a principle of construction requiring the courts to choose, whenever possible, the interpretation that is most compatible with Community principles. It would also give the [European Court of Justice] ultimate jurisdiction in matters of interpretation.

Id. at 23-24. For a discussion of the obligation of national executive and judicial authorities to defer to European-wide norms, see John Temple Lang, The Duties of National Courts Under Community Constitutional Law, 21 EUR. L. REV. 3 (1997); John Temple Lang, The Duties of National Authorities Under Community Constitutional Law, 23 EUR. L. REV. 109 (1998). 
member-states. Thus, these rights are not encompassed in the "common traditions" of the European Union which prevail, to the detriment of the principle of subsidiarity. ${ }^{106}$

On a more global level, the United Nations Development Program (UNDP), in its official Human Development Report 2002, a document that was entitled that year Deepening Democracy in a Fragmented World, hailed the new International Criminal Court in terms nearly identical to those set out by Kelsen regarding limits to traditional notions of national sovereignty. ${ }^{107}$

Kelsen disallows that the creation of international organizations by treaties entered into by individual nation-states in anyway limits the claims of the new organization with respect to their constituting sovereignties.

It may be objected that the individual state cannot be conceived as an order delegated by international law, because historically the states-the national legal orders-preceded the creation of general international law, which was established by custom prevalent among states. This objection, however, is based on the lack of differentiation between the historical relation of facts and the logical relation of norms. The family too, as a legal community, is older than the state which embraces many families; and yet the validity of family law is based upon the national legal order. In the same way, the validity of the order of a single member state is based upon the constitution of the federal state, although the latter's creation is later in time than the formerly independent states which only subsequently gathered together in a federal state. Historical and normative-logical relations should not be confounded. ${ }^{108}$

106. See Leonard F.M. Besselink, Entrapped by the Maximum Standard: On Fundamental Rights, Pluralism and Subsidiarity in the European Union, 35 COMMON MKT. L. REV. 585 (1998). The complications that have arisen due to the application of overarching supranational jurisdiction over national jurisdictions ranges from matters of family law to those of environmental regulations. See, e.g., Adelina Adinolfi, The Judicial Application of Community Law in Italy (1981-1997), 35 COMMON MKT. L. REV. 1227, 1313-69 (1998). See also Hans Petter Graver, Mission Impossible: Supranationality and Nationality Legal Autonomy in the EEA Agreement, 7 EUR. FOREIGN AFF. REV. 73 (2002).

107. UN Development Programme, Human Development Report 2002: Deepening Democracy in a Fragmented World, 105-07 (2002) [hereinafter Human Development Report 2002]. "International relations have long been based on state sovereignty and sovereign immunity ... the establishment of a widely ratified international court is promising innovation. ... It limits territorial sovereignty by making leaders accountable to external standards." Id.

108. PTL, supra note 34, at 338-39. See also Human Development Report 2002, supra note 106. It chronicles approvingly the establishment of new international tribunals, noting " $[t]$ hese new processes challenge the traditional intergovernmental model of international relations." Id. at 108. 
There is a subtle, but significant, maneuver in this affirmation. While Kelsen recognized that international law emerged at a later stage in history than national, and that there was a time when the law of the nation-state was the supreme norm, his focus on the principle of efficacy means that he can both assert that the pre-international national system was valid-their thenvalidity being determined by some other, unexplained, method-and that their present validity nonetheless depends on the international system. According to Kelsen, this principle, which, as a norm of international law, determines the territorial sphere of validity of the state order, becomes, when he focuses on the analysis of the concept of a legal system, a condition of validity. As he asserted in his earlier work General Theory of Law and the State, "[a] norm is considered to be valid only on the condition that it belongs to a system of norms, to an order which, on the whole, is efficacious." 109 Hence, without recourse to the norm of international law, Kelsen reaffirms the validity of these pre-international national systems with an appeal to efficacy. Once the international system is established, he asserts the primacy of the international legal system over the national legal system and postulates that the national legal systems derive their validity from the basic norm of international law.

Thus, Kelsen's legal theory arrives back at the question of the basic norm (Grundnorm), a concept which, according to the author, is hypothetical. Paraphrasing Kant, this is the postulate of juridical reason that Kelsen's project needs in order to cement its structure. This hypothetical and presupposed basic norm is needed, according to the logic of Kelsen's philosophy, not only to assure the validity of lower order norms, but also that of the international legal system itself: "As a genuine basic norm, it is a presupposed-not a positive norm. It represents the presupposition under which general international law is regarded as the set of objectively valid norms that regulate the mutual behavior of states ... . These norms are interpreted as legal norms binding the states . . . "110 The national laws of states constitute merely a "partial system" in relation to the universal jurisdiction of the international legal system. Thus, domestic norms can never conflict with international ones, on pain of nullity.

In the purely logical system constructed by Kelsen's legal philosophy, there is no place for rights that precede the state, since the recognition of such rights would lead, according to the logic of his theory, into the intolerable subordination of the state to those rights. This concern is all the more applicable in the case of the supranational state and its global legal monopoly, even at the expense of states. The individual must simply obey the law because it is established as a norm by the state, and not because it is a just law 
deriving from reason or nature, much less from a divine command. ${ }^{111}$ In Kelsen's system, the validity of a norm is assured if its emanation conformed with the established procedure for the creation of norms, that is, it is based on the preceding level of norms and so on, back to the hypothetical, presupposed basic norm of the superiority of the supranational legal system. It is a question of process rather than content as Kelsen made explicitly clear:
[A]n individual who regards the law as a system of valid norms has to disregard morals as such a system, and one who regards morals as a system of valid norms has to disregard the law as such a system. ... [N]o viewpoint exists from which both morals and law may simultaneously be regarded as valid normative orders. No one can serve two masters. ${ }^{112}$

This is what renders Kelsen's philosophy of law, distilled as it was in academia, a potent ideology in the international political sphere for those who would look to the United Nations as the nucleus for global governance. ${ }^{113}$ What is decided according to the procedures of the U.N. Charter is normative and binding, irrespective of content. And because the mechanisms of the Charter favor "consensus," the "consensus" of the world body determines what ought to occur or not occur. In fact, many of the recent criticisms of "unilateralism" by proponents of a "multilateral" approach echo Kelsen's division of legal theorists into those with "subjectivistic" viewpoints and “objectivistic" vision:

111. See, e.g., DAS NATURRECHT IN DER POLITISCHEN THEORIE. INTERNATIONALES FORSCHUNGSZENTRUM FÜR GRUNDFRAGEN DER WISSENSCHAFTEN IN SALZBURG 1-37 (Franz Martin Schmölz ed., 1963). Kelsen himself admitted that, as a logical consequence of the "Pure Theory," even monstrous perversions of jurisprudence such as the "justice" meted out by totalitarian regimes would qualify as "legal." In the discussion following his conference on Die Grundlage der Naturrechtslehre ("Foundation of the Theory of Natural Law") he stated:

From the point of view of juridical science, the legal system established by the Nazi regime was one of law. We can regret it, but we cannot deny that it was a rule of law. The legal system of the Soviet Union is one of law! We can deplore it as we would a venomous serpent, but we cannot deny that it exists and can say what it will.

Id. at 148. Although Kelsen's address was subsequently translated into English and published as Hans Kelsen, Foundation of Natural Law Doctrine, 2 ANGLO-AM. L. REV. 87 (1973), the discussion section of the Salzburg conference was omitted by the translator.

112. PTL, supra note 34, at 329.

113. See Charles Leben, Hans Kelsen and the Advancement of International Law, 9 EuR. J. INT'L LAW 287 (1998). The author, who is unabashedly enthusiastic about increasing intermational jurisdiction, observed that:

The particularly fascinating point of Kelsen's thinking is not only the cogency and rigor of his reasoning but also the fact that his work, which was reputed to be theoretical, even dogmatic, and remote from the concerns of the real world, provides us with the sharpest conceptual tools with which to think through the contemporary developments of international law. 
The subjectivistic view starts from the sovereign Self in order to conceive the external world. . . The subjectivistic, egocentric interpretation of the world leads to solipsism, that is, the view that only one's Self exists as a sovereign being ... in the same way the primacy of national legal order means that only one's own state can be conceived as being sovereign. . . . With this in mind, we can describe the primacy of one's own national legal order as state subjectivism, indeed as state solipsism. The objectivistic world view starts from the reality of the external world in order to conceive the Self ... but does not allow this Self to exist as a sovereign being . . . but only as an essential part of the world; in the same way the construction described as primacy of the international legal order starts from the external world of law, international law, as valid legal order, to conceive of the legal existence of individual states, but cannot afford to consider them as sovereign authorities-only as partial legal orders integrated into international law. ${ }^{114}$

In this "objectivistic" scheme, the individual state is "bound by a majority decision of a collegiate organ" of the international system as long as the "this collegiate organ and its procedure has been created by a treaty concluded by the state," 115 as well as by the decisions of international tribunals which can declare norms of national law "annulled for reasons of being "contrary to international law." 116 However, as the younger Kelsen conceded, in an observation that goes far in explaining the visceral reactions to the American hyperpuissance, that for this project to work, it is:

Possibly exclusively through the aid of a legal hypothesis: that above the legal entities considered as states there is a legal system that delimits the spheres of validity of the individual states, preventing interference by one in the sphere of the other, or associating such interference with certain conditions that are equal for all. That is, it is essential for there to be a legal system regulating, through norms equal for all, the reciprocal conduct between these entities and excluding at the root, as regards the legal relations between the individual states, any legal overvalue of one vis-à-vis the other .... It is only on the basis of the primacy of the 
international law that the particular states appear on the same legal plane and can count legally as entities of equal rank, being subject equally to the higher international legal system. ${ }^{117}$

As noted previously, what constitutes this international legal system is "consensus"-driven, not only by an international "community" of theoretically equal sovereign nation-states, ${ }^{118}$ but also the "community" constituted of intergovernmental bodies like the United Nations and its related tribunals and agencies, the international non-governmental organizations who have associated with the globalist agenda of the world body, ${ }^{119}$ and the international class of bureaucrats who staff both sets of organizations. ${ }^{120}$

It is not that leading exponents of this international "community" act furtively or hide their ambitions. In an essay commissioned for the UNDP Human Development Report 1994, Jan Tinbergen, winner of the first Nobel Prize for Economics in 1969, called for nothing less than a single world government:

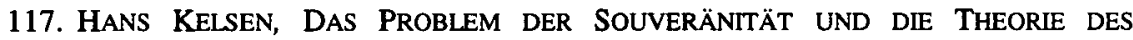
VÖLKERRECHTS. BEITRAG ZU EINER REINEN RECHTSLEHRE (1920).

118. For an interesting critique of the surrealism of this theoretical equality when confronted with geopolitical reality, see Michael J. Glennon, Why the Security Council Failed, FOREIGN AFF., 16 (May-June 2003). Glennon observed:

This year, the irrationality of treating states as equals was brought home as never before when it emerged that the will of the Security Council could be determined by Angola, Guinea, or Cameroon-nations whose representatives sat side by side and exercised an equal voice and vote with those of Spain, Pakistan, and Germany. The equality principle permitted any rotating council member to cast a de facto veto (by denying a majority the critical ninth vote necessary for potential victory). Granting a de jure veto to the permanent five was, of course, the charter's intended antidote to unbridled egalitarianism. But it didn't work: the de jure veto simultaneously undercorrected and overcorrected for the problem, lowering the United States to the level of France and raising France above India, which did not even hold a rotating seat on the council during the Iraq debate. Yet the de jure veto did nothing to dilute the rotating members' de facto veto. The upshot was a Security Council that reflected the real world's power structure with the accuracy of a fun-house mirror-and performed accordingly.

Id. at 33.

119. These NGOs include not only the well-known advocacy groups, but also organizations whose issue is itself global governance. A notable example is the self-styled "Commission on Global Governance," an organization made up of former United Nations officials and political leaders from a number of developed and developing countries that was endorsed by the U.N. Secretariat. It has even published a detailed program for an expanded international system: Commission on Global Governance, Our Global Neighborhood: The Report of the Commission on Global Governance (1995).

120. For information on the bureaucracy of the United Nations and its subordinate institutions, see ROSEMARY RIGHTER, UTOPIA LOST: THE UNITED NATIONS AND WORLD ORDER (1995). For a dated but, in retrospect, exceptionally prescient study, see Doug Bandow, Totalitarian Global Management: The UN's War on the Liberal International Economic Order, Cato Pol'y Analysis No. 61 (1985). 
Mankind's problems can no longer be solved by national governments. What is needed is World Government.

This can best be achieved by strengthening the United Nations system. In some cases, this would mean changing the role of UN agencies from advice-giving to implementation. Thus the FAO would become the World Ministry of Agriculture, UNIDO would become the World Ministry of Industry, and the ILO the World Ministry of Social Affairs.

In other cases, completely new institutions would be needed. These could include, for example, a permanent World Police which would have the power to subpoena nations to appear before the International Court of Justice, or before specially created courts. If nations do not abide by the Court's judgment, it should be possible to apply sanctions, both non-military and military. ${ }^{121}$

It would hardly be fair to blame Hans Kelsen for the excesses of the United Nations and other international organizations that are increasingly ambitious in their quest for a system of global governance. The late jurist was, after all, working within a theoretical framework at a time when the horrors of two world wars caused many to look for a new Kantian-inspired "state of universal peace" to be brought about by a benevolent world government. ${ }^{122}$ Kelsen himself thought of the ideas expounded in his Pure Theory of Law as "a theory of positive law in general, not of a specific legal order . . not an interpretation of specific national or international legal norms." 123 He even cautioned that he offered a theory that described "what and how the law is, not how it ought to be." 124 However, in proposing a "pure theory of law" that attempted to eliminate all considerations of ethics and political theory, Kelsen admittedly created a philosophy of law that was indifferent to these other considerations, ${ }^{125}$ thus leaving open the door to a course of evolution that his theory, even if it did not actively encourage it, had no instrument with which

121. United Nations Development Program, Human Development RePort 1994, 88 (1994).

122. See IMMANUEl KaNT, PERPETUALPEACE AND OTHER ESSAYS ON POLITICS, History, AND MORALS (Ted Humphrey trans., 1992). The European adoption of this Kantian vision in contrast to the American retention of a Hobbesian worldview is the subject of fascinating thesis, originally raised in an essay published in POL'Y REV., expounded in a brief book. See also ROBERT KAGAN, OFPARADISE AND POWER: AMERICA AND EUROPE IN THENEW WORLD ORDER (2003).

123. PTL, supra note 34 , at 1 .

124. Id.

125. Id. at $345-47$. 
to judge, much less arrest. ${ }^{126}$ As Juvenal once asked: "Quis custodiet ipsos custodes?"127

Not long after the attacks of September 11, Ambassador Richard N. Haass, director of the Office of the Policy Planning Staff of the U.S. State Department, defined the American administration's policy as "hardheaded multilateralism," explaining that:

We are willing to listen, learn, and modify policies when we hear compelling arguments. But we will not go along simply to get along. By the same token, we do not take lightly the "costs" to ourselves and to others when we forego participation in some multilateral initiative. In the future, we will give consultations every "reasonable" chance to produce an acceptable compromise. And if we conclude that agreement is beyond reach, we will explain why and do our best to put forth alternatives. ${ }^{128}$

In this regard, a "decent respect for the opinions of mankind," to borrow the felicitous phrase of the Founding Fathers, will require an effort to recognize and understand, regardless of whether one agrees with it or not, Kelsen's philosophy of law and its significance as the legal ideology that motivates the insistence of international organizations, like the United Nations, as well as other countries on "consensus" and their drive for a system of global governance. While the former insistence is frustrating and the latter ambition may seem far-fetched and beyond the horizons of today's political landscape, it nonetheless behooves one to keep in mind the warning of philosopher Richard Weaver that "ideas have consequence."129 And in a dynamic geopolitical continuum, the forgotten theories of yesterday are all-too-often the hidden perils of today and the real challenges of tomorrow.

126. On at least one occasion, however, Kelsen did throw methodological caution to the winds and ventured into advocacy. See KELSEN, supra note 116, at 319.

It is only temporarily, by no means forever, that contemporary humanity is divided into states, formed in any case in more or less arbitrary fashion. Its legal unity, that is the civitas maxima as organization of the world: this is the political core of the primacy of international law, which is at the same time the fundamental idea of that pacificism which, in the sphere of international politics, constitutes the inverted image of imperialism.

Id.

127. JUVENAL, SATIRES, VI, 347-48.

128. Richard N. Haass, American Foreign Policy After September 11th, Remarks to the World Affairs Council of Northern California (Nov. 16, 2001), at http://www.state.gov/s/p/rem/6310.htm (last visited Mar. 5, 2004).

129. RICHARD M. WEAVER, IDEAS HAVE CONSEQUENCES (1984). 